\title{
WestVirginiaUniversity
}

THE RESEARCH REPOSITORY @ WVU

Graduate Theses, Dissertations, and Problem Reports

1999

\section{Occurrence, etiology and management of ringwomb in ewes}

Nancy Jean Kerr

West Virginia University

Follow this and additional works at: https://researchrepository.wvu.edu/etd

\section{Recommended Citation}

Kerr, Nancy Jean, "Occurrence, etiology and management of ringwomb in ewes" (1999). Graduate Theses, Dissertations, and Problem Reports. 981.

https://researchrepository.wvu.edu/etd/981

This Thesis is protected by copyright and/or related rights. It has been brought to you by the The Research Repository @ WVU with permission from the rights-holder(s). You are free to use this Thesis in any way that is permitted by the copyright and related rights legislation that applies to your use. For other uses you must obtain permission from the rights-holder(s) directly, unless additional rights are indicated by a Creative Commons license in the record and/ or on the work itself. This Thesis has been accepted for inclusion in WVU Graduate Theses, Dissertations, and Problem Reports collection by an authorized administrator of The Research Repository @ WVU. For more information, please contact researchrepository@mail.wvu.edu. 


\title{
Occurrence, Etiology and Management of Ringwomb in Ewes
}

Nancy Jean Kerr, B.S.

Thesis submitted to the College of Agriculture, Forestry and Consumer Sciences

West Virginia University in partial fulfillment of the requirements

for the degree of

\section{Master of Science \\ In \\ Animal and Veterinary Sciences}

\author{
Robert A. Dailey, Ph.D., Chair \\ E. Keith Inskeep, Ph.D. \\ Paul E. Lewis, Ph.D. \\ Division of Animal and Veterinary Sciences
}

\section{Morgantown, WV}

1999

Keywords: Early Dilation Syndrome, Ovine Dystocia, Parturition, Abortion, Vaginal Prolapse Copyright 1999 Nancy Jean Kerr 


\title{
ABSTRACT \\ Occurrence, Etiology and Management of Ringwomb in Ewes
}

\author{
Nancy Jean Kerr \\ Pedigrees of ewes with Ringwomb were studied to determine the etiology, incidence and \\ treatment of Ringwomb. Purebred Suffolk and crossbred Hampshire and Shropshire ewes aged \\ from one to seven years were observed over a period of five lambing seasons. The study was \\ conducted on 24 clinical cases of ringwomb occurring in one flock. Ringwomb or incomplete \\ cervical dilation accounted for an incidence of 20.5\% (24/117) of all ewes lambing. The ewes \\ affected were all daughters, granddaughters, or great-granddaughters of one particular sire used \\ on the farm as a service sire. Because ringwomb does not typically affect ewes in two \\ consecutive seasons, it is concluded that the occurrence of ringwomb is dependent upon the \\ genotype of the fetus. The author concludes that the service sire introduced an autosomal \\ recessive gene into the ewe flock and that the phenotype was not displayed until the carrier \\ daughters were serviced by another carrier.
}

Keywords: Early Dilation Syndrome, Ovine Dystocia, Parturition, Abortion, Vaginal Prolapse 


\section{ACKNOWLEDGEMENTS}

It would be impossible for me to express my gratitude to those who assisted me throughout my studies at WVU. I would first of all like to thank Dr. Robert A. Dailey for his assistance, criticism and guidance throughout my graduate training. I am grateful to Dr. E. Keith Inskeep for his continuous assistance, comments and encouragement that allowed me to broaden my

knowledge. I am indebted to Dr. Paul E. Lewis for the opportunity to explore West Virginia and to meet real sheep producers.

A special thanks goes to my fellow graduate students, Rob Taft, James Gekara, Greg Farris, Amanda Barker, and Melissa McCormick for their help and assistance with computer techniques. I would also like to thank Lisa Williams, Timothy Daniel Maze, Marlon Knights, Beth Costine and Phyllis Bridges for their encouragement, comments, and advice.

I thank Jim Pritchard II for his assistance with data collection and cooperation. Finally, I thank my parents for their understanding and patience throughout my college career. 


\section{TABLE OF CONTENTS}

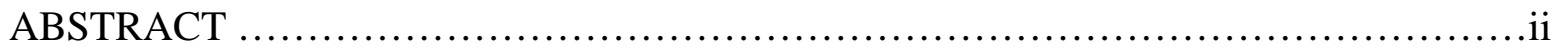

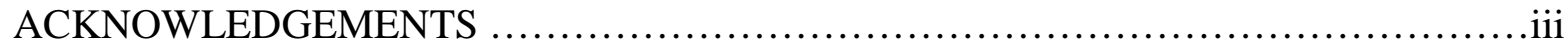

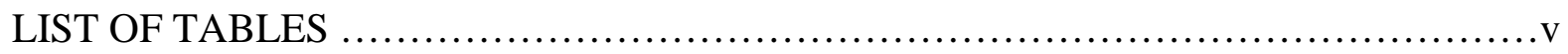

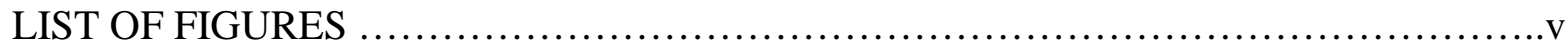

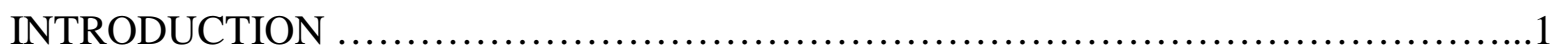

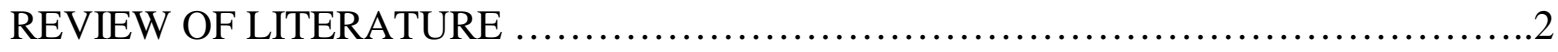

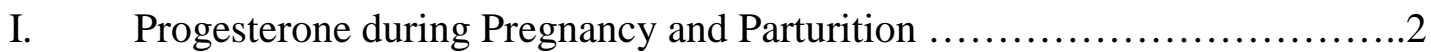

II. Estrogen during Pregnancy and Parturition ............................

III. Hormonal Regulation of Parturition ...................................4

IV. Changes of the Cervix Throughout Gestation and During Parturition ........8

V. Parturition ..........................................................

VI. Ringwomb ................................................... 10

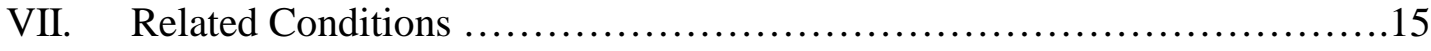

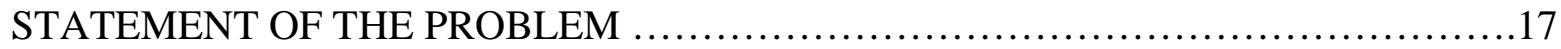

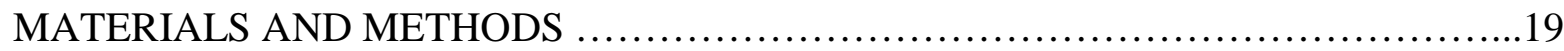

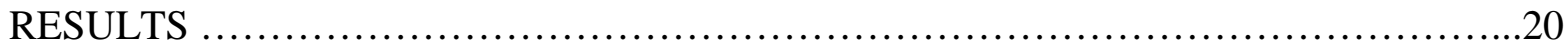

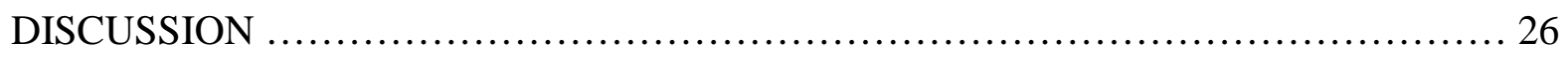

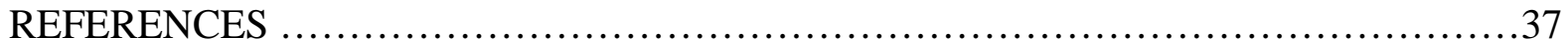

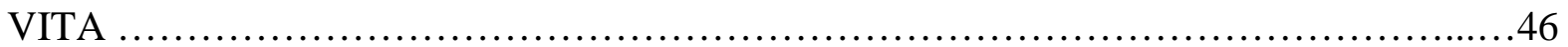




\section{LIST OF TABLES}

$\underline{\text { Table }}$

1. Parity and age of ewes with Ringwomb and Early Dilation Syndrome (EDS) in

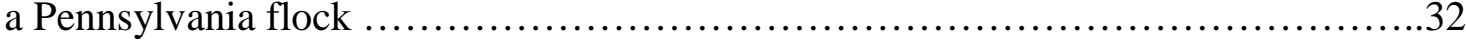

2. Incidence of Ringwomb and Early Dilation Syndrome grouped by parity and age in a Pennsylvania flock during 1993-97 .....................................

3. Number of ewes serviced and number of female offspring with Ringwomb in a Pennsylvania flock during 1993-97

\section{LIST OF FIGURES}

\section{$\underline{\text { Figure }}$}

1. Occurrence of Ringwomb in one selected ewe family showing transmission of an autosomal recessive trait

2. Occurrence of Early Dilation Syndrome in a selected maternal bloodline 


\section{CHAPTER 1}

\section{INTRODUCTION}

Failure of the cervix to dilate completely is a relatively common cause of dystocia in dairy cattle, sheep, and goats. Ringwomb may occur both in the primiparous and the multiparous animal. It is most likely to be the outcome of hormonal dysfunction for the course of labor in most cases is atypical. Ringwomb is difficult to ascertain accurately how long labor has been existent. Often the amniotic sac has passed through the cervix and vulva, and may have ruptured with escape of amniotic fluid.

The incidence of failure of the cervix to dilate varies widely both between flocks and from season to season. Because dystocia inevitably results in reduced lamb and ewe survival, there is always the question of future breeding of affected ewes. Since previous studies do not consistently support an association between incidence, etiology, or treatment of ringwomb, it is necessary to conduct a study to determine the occurrence, etiology and management of ringwomb in ewes. Previous studies and findings have been reviewed in this thesis, and the results of the study mentioned above have been presented. 


\section{CHAPTER 2}

\section{REVIEW OF LITERATURE}

Knowledge of the mechanisms responsible for initiating parturition and the role of the fetus in parturition are requisites to understanding the occurrence, etiology, and management of ringwomb. To understand any abnormal process or condition, it is necessary to clearly understand the normal process. Discussion of the control of parturition and the occurrence of Ringwomb will be divided into these categories: progesterone during pregnancy and parturition, estrogen during pregnancy and parturition, hormonal regulation of parturition, changes in the cervix throughout pregnancy and during parturition, normal parturition, ringwomb, and related conditions.

\section{Progesterone During Pregnancy and Parturition}

Production of progesterone in the pregnant sheep is derived from the corpus luteum during the first 55 days of pregnancy (39), but there is a gradual decline in ovarian progesterone secretion thereafter (31). Thus, ovariectomy after day 55 does not cause abortion, because placental progesterone production is adequate to maintain pregnancy (31). Following ovariectomy, the serum concentrations achieved by exogenous progesterone that are necessary to maintain pregnancy between days 50-90 are surprisingly low $(0.5--1.0 \mathrm{ng} / \mathrm{ml})$. Both in intact sheep and following ovariectomy, the plasma progesterone concentration increases steadily from day 85-90 reaching a maximum around days 125-130 of gestation (45). Concentrations of 
progesterone in jugular blood between days 80 to 130 in ewes depend on the number of fetuses in the uterus (62). The concentration of progesterone in plasma decreases in a variable manner over the last 5 to 15 days of pregnancy (45). The decrease in progesterone results from the increase in fetal plasma corticosteroids seen at term. Placental secretion of progesterone may be affected by exogenous estrogens. Ewes grazing Yarloop clover, an estrogenic pasture species, have 50 percent lower progesterone from day 90 until parturition than ewes grazing ryegrass, a non-estrogenic pasture species (48).

Among many other actions, progesterone opposes many effects of estrogens and it suppresses the synthesis of oxytocin receptors and gap junctions. Under the influence of progesterone the innervation of the uterus becomes very sparse, and the myometrium is predominantly under the influence of inhibitory $\beta$-receptors. In contrast to estrogen, which promotes the softening action of relaxin and collagenases on the cervix, progesterone inhibits the softening by relaxin.

\section{Estrogen During Pregnancy and Parturition}

In sheep, concentrations of estradiol-17 $\beta$ remain similar through day 130 of gestation, but increases thereafter (55). In a study by Carnegie and Robertson (71), estradiol-17 $\alpha$, estradiol$17 \beta$, estrone, and their sulfur conjugates were measured in amniotic fluid, allantoic fluid or in

ovarian, uterine, or jugular venous blood of sheep. Three stages of estrogen production appeared to occur between days 0 to 55 , days 55 to 140 , and days 140 to 150 .

During the last trimester, total estrogens are highly correlated to the number of fetuses (76). The principal estrogen based on mass is estrone sulfate, which appears to come from the fetus as early as day 30 of gestation. Concentrations of estrogen are consistently higher in fetal than in 
maternal fluids. However, the placenta may modify the form seen in maternal blood (56). Fetal membranes are capable of estrogen synthesis and produce mainly less active estrone and estradiol-17 $\alpha$. They are conjugated into water-soluble sulfates in fetal liver, pass the placenta, and are excreted in maternal urine. Fetal maturation therefore depends on a functioning fetal endocrine system. Early fetal development is independent of endocrine influences, but late development and maturation depend on endocrine secretions, particularly insulin, thyroid, and adrenal hormones.

Estrogens are necessary for the action of progesterone because they regulate the formation of progesterone receptors and progesterone in turn down-regulates estrogen receptors. Estrogens promote contractility because they induce the synthesis of contractile proteins and enzymes necessary for energy production and because they induce synthesis of myometrial receptors for uterotonic agonists, such as oxytocin, $\alpha$-adrenergic compounds, and some prostanoids, and suppresses receptors for inhibitory agonists, such as $\beta$-adrenergic compounds. Estrogens induce gap junction formation, which promotes coordination of myometrial contractions, and in progesterone-exposed animals estrogens increase endometrial prostaglandin synthesis.

\section{Hormonal Regulation of Parturition}

The onset of parturition, although not completely understood, is brought about in part by a gradual increase in the secretion of estrogens from the placenta that occurs late in gestation. About 20 days before birth, the fetal lamb pituitary gland begins to increase the secretion of ACTH (adrenocorticotropin), stimulating the synthesis of the enzymes that convert progesterone to estrogen. Thus, placental progesterone production and consequently concentration of 
progesterone in maternal plasma falls, and concentration of estrogen in maternal plasma rises.

Estrogen stimulates prostaglandin production by the placentomes and fetal membranes as well as increasing maternal secretion of oxytocin.

The changes in hormone secretion immediately before birth have been studied thoroughly in sheep. That the fetus influences its own birth is well established. The sequence of events in parturition starts with activation of the hypothalamus and pituitary of the fetus. About five days before birth, a further increase in ACTH secretion stimulates the fetal adrenal glands to liberate cortisol. Cortisol acts on steroid-secreting cells of the fetal cotyledon, which have been actively secreting the progesterone essential for maintenance of the pregnancy. The placenta of the ewe produces progesterone from cholesterol but lacks a key enzyme in the pathway from progesterone to estrogen. Cortisol induces $17 \alpha$-hydroxylase, an enzyme that in effect switches steroid production from progesterone to $17 \alpha$-hydroxypregnenolone. Fetal adrenal cortisol also induces the enzyme 17,20 - desmolase, which converts $17 \alpha$-hydroxypregnenolone to dehydroepiandrosterone. Dehydroepiandrosterone is converted to androstenedione. Fetal adrenal cortisol enhances aromatase activity to convert androstenedione to estrone, which is secreted, and estradiol - 17 $\beta$. Fetal estrogen crosses the placenta where it becomes unconjugated estradiol. At the same time the clearance rate of progesterone increases. The shift in hormonal balance results in increased posterior pituitary oxytocin content, increased number of gap junctions, and increased density of oxytocin receptors in myometrium, cervical mucosa, and fetal membranes.

The change to dominance of estrogen over progesterone is important in several respects, but particularly in the production of prostaglandin $\mathrm{F}_{2 \alpha}\left(\mathrm{PGF}_{2 \alpha}\right)$ in the cells of the myometrium and maternal placenta. Unconjugated estrogens promote, whereas progesterone inhibits, the 
synthesis of $\mathrm{PGF}_{2 \alpha}$ in sheep. Conversely, the enzymatic degradation of prostaglandins is enhanced by progesterone throughout pregnancy, but is depressed by the dominance of estrogen during the last few days before birth. Thus, the endocrine changes promote the production of $\mathrm{PGF}_{2 \alpha}$ and of $\mathrm{PGE}_{2}$, both of which are powerful stimulants of uterine muscle for contraction. Uterine contractions themselves then facilitate further release of the intracellular liposomal enzymes that synthesize prostaglandins, and the whole process becomes self-perpetuating.

The ultimate effect of uterine contraction, in combination with cervical relaxation and other changes, is to advance the fetus into the cervix and anterior vagina, which will elicit the release of oxytocin. Oxytocin augments the myometrial contractions, with the liberation of even more prostaglandins, so that the whole sequence takes on a cascading effect. The significance of this cascade and the reflex synchronized abdominal effort is to increase the efficiency and decrease the duration of second-stage labor, when the risks of anoxia and other hazards are maximal.

Importantly, a number of workers have observed that exogenous progesterone cannot block parturition, either normal or induced, unless given in very high doses (e.g. $200 \mathrm{mg} / \mathrm{day})(35,52)$. However, the experiments of Liggins et al. (52) showed that despite large amounts of progesterone being administered to pregnant ewes, concentrations of progesterone in plasma failed to increase greatly and it seemed that the progesterone was being cleared rapidly by the placenta and being converted partly to estrogen. Flint et al. (64) showed that following the increase in the fetal cortisol before parturition, the placental enzymes are induced, and there is a quantitative conversion of placental progesterone to estrogen.

In many corpus luteum-dependent species administration of progesterone prolongs pregnancy, but in species that depend on placental progesterone this is not the case. Thus, when exogenous progesterone is administered in an attempt to block parturition it probably increases 
circulating concentrations of estrogen. Consistent with this view, Liggins et al. (52) reported a very high free estradiol- $17 \beta$ concentration $(700 \mathrm{pg} / \mathrm{ml})$ in a ewe in which dexamethasone-induced parturition was blocked with progesterone. Even if a synthetic progestagen is used, the conversion of all the placental progesterone to estrogen as well as the conversion of $\mathrm{C} 19$ steroids from the fetal and maternal adrenals to estrogen may well lead to high concentrations of estrogen in the maternal circulation. In the sheep, large doses of estrogen can induce uterine activity and parturition in ewes near term $(41,60)$. However, this situation is associated frequently with prolonged labor and cervical dystocia. It would appear therefore, that the failure of low doses of progesterone to block parturition in sheep cannot be used as an argument against progesterone as a "myometrial blocker" in sheep.

Prostaglandins have been found to be regulators of myometrial contractility and essential elements in the onset of myometrial contractility and in the onset and progression of labor. The rise in concentrations of prostaglandins in amniotic fluid at the time of labor is accompanied by an increase in the concentration of free arachidonic acid, suggesting that liberation of this substrate for eicosanoid production may be critical. Further, there are increases in the concentrations of 6-keto- $\mathrm{PGF}_{1 \alpha}$, the hydrolytic breakdown product of $\mathrm{PGI}_{2}$. This observation is of interest since it may reflect directed endoperoxide metabolism towards stimulatory prostaglandins and away from $\mathrm{PGI}_{2}$, which, in women and sheep, may have inhibitory actions on myometrial contractility.

In near-term sheep, the highest concentrations of prostaglandins in intrauterine tissues are found in the chorioallantois and cotyledons. Administration of ACTH to chronically catheterized fetal lambs increased the concentrations of $\mathrm{PGF}_{2 \alpha}$ and 6-keto- $\mathrm{PGF}_{1 \alpha}$ in chorioallantois and cotyledons and $\mathrm{PGE}_{2}$ in endometrium. There was no elevation of 
prostaglandins in amniotic tissue. The administration of indomethacin in the presence of ACTH infusion significantly decreased intrauterine contractions (117).

The availability of free calcium is a major factor influencing prostaglandin output by fetal membranes. It has been suggested that the probable mechanisms of calcium action include stimulation of phospholipases $A_{2}$ and $C$; and inhibition of the enzyme diacylglycerol kinase, thereby preventing the resynthesis of phophatidylinositol.

\section{Changes of the Cervix Throughout Gestation and During Parturition}

During the course of gestation, changes occur in the metabolism and chemical composition of the cervical connective tissue. The concentrations of collagen, proteoglycan and hyaluronase in the cervix decrease late in gestation, while there is a small but significant increase in tissue hydration. The collagen network loses its dense, ordered appearance and assumes a loose, frayed, disoriented structure.

Cervical ripening and dilation in the ewe have been quantified in terms of the connective tissue content of the tissue and the biosynthesis of the macromolecular components which make up the extracellular matrix. During pregnancy there is a marked increase in the total tissue mass of the cervix along with the total mass of hydroxyproline (collagen) and hexuronare (proteoglycans and hyaluronate) (81).

In a study using the activity of a leukocyte-specific enzyme, myeloperoxidase, to quantify changes in leukocyte concentration in the ovine cervix during pregnancy, it was observed that leukocytes could participate in cervical connective tissue reorganization during dilation at parturition and in postpartum involution of the cervix. Labor in sheep is associated with leukocytic invasion of the cervix (110). 
The effects of an inhibitor of $3 \beta$-hydroxysteroid dehydrogenase (epostane) on uterine activity and cervical softening have been studied in sheep during late pregnancy (82). Treatment with epostane led to a rapid decline in the concentration of progesterone measured in utero-ovarian venous plasma. This was followed by a significant increase in the concentrations of metabolites of prostaglandins $\mathrm{E}$ and $\mathrm{F}$ in utero-ovarian venous plasma and uterine activity similar to that seen in the final stages of normal labor. Infusion of mefenamic acid, an inhibitor of prostaglandin synthesis, prevented the changes in uterine activity and cervical softening that occurred after injection of epostane alone. Mefenamic acid also reduced the increase in concentrations of metabolites of prostaglandins $\mathrm{E}$ and $\mathrm{F}$ in plasma, although the concentration of progesterone in these animals showed the same abrupt fall that occurred in ewes after injection of epostane alone. Progesterone withdrawal, in the absence of any subsequent rise in circulating estrogen concentration, is a sufficient stimulus to induce cervical softening in the ewe. Cervical softening following progesterone withdrawal can be prevented by inhibition of prostaglandin synthesis (110).

\section{$\underline{\text { Parturition }}$}

Parturition is divided into three stages: (a) preparation; (b) expulsion of the fetus; and (c) expulsion of the placenta. The preparatory stage is characterized by dilation of the cervix and rhythmic contractions of the longitudinal and circular muscles of the uterus. These contractions

force the fetal fluids and membranes against the relaxed cervix, causing it to dilate. At the end of this stage, the cervix expands, allowing the uterus and vagina to become a continuous canal. The 
fetus and chorioallantois are forced into the pelvic inlet where the chorioallantois ruptures, resulting in allantoic fluid flowing from the vulva.

The second stage begins when the distended amnion along with the head and part of the extremities are forced into the pelvic inlet. The presence of these parts of the fetus initiates reflex and voluntary contractions of the diaphragm and abdominal muscles. The passage of the fetus through the cervix into the vagina along with rupture of one or both of the fluid filled amnion and chorioallantois initiates reflex contractions, which force the fetus through the birth canal.

The fetus is expelled while still attached to the fetal membranes. The maternal cotyledons continue to supply oxygen from the ewe even if the expulsion is prolonged. The last fetal cotyledons are not detached from the maternal cotyledons until after the lambs are born, thus ensuring an oxygen supply until the young are able to breathe independently.

The expulsion of the fetal membranes is an active process associated with uterine contraction. Normally the placenta of the ewe is delivered within 2 to 8 hours following parturition.

\section{Ringwomb}

Ringwomb is defined as failure of the cervix to dilate at parturition. Failure of the cervix to dilate may be caused by failure of secretion of the hormones that control labor or of the tissue response to hormonal secretions. Ringwomb causes sporadic dystocia, mainly in multiparous ewes bearing multiple fetuses. Ringwomb has no predisposition associated with breed, age, or body condition score, but is associated with a significantly higher lambing percentage. The condition has been reported to be responsible for $15-32 \%$ of cases of ovine dystocia (83). 
Breed and Body Condition. Ringwomb has been observed in purebred and crossbred ewes. Hindson and Turner (34) reported cases in Clun Forest, Dorset Horn, Suffolk, Border Leicester, South Devon, Kerry Hill, and halfbred ewes. Body condition of affected ewes does not differ significantly from non-affected animals in the same flock (34).

Age of Ewe. Hindson and Turner (34) reported 4 cases -2 years old; 9 cases -3 years old; 17 cases— 4 years old; 14 cases—over 4 years old. The pelvic size of immature ewes has been suspected as one possible cause, but the majority of the cases occur in ewes over two years of age (37). Recorded incidence of cases show that the majority of cases occur in ewes 2 years or older.

Number of Lambs. Ringwomb has been associated with ewes bearing multiple lambs. Hindson and Turner (34) reported the following observations: six ewes had one lamb; 32 ewes had two lambs; and three ewes had three lambs.

Parity. Majeed (104) observed ringwomb in primiparous and two-year-old ewes having twin or triplet pregnancies. Hindson and Turner's study included ewes that had had two known lambings $(34,41)$. There is some confusion relating ringwomb to premature lambing detected by lack of milk (34). This could result from an inability to differentiate between Ringwomb and Early Dilation Syndrome, or a hormonal interference (deficient relaxin) inhibiting lactogenesis (114). 
Reports of ringwomb or incomplete cervical dilation have occurred since the 1930s. In 1952, Mackinnon and Bayliss (6) described ringwomb as a fairly common condition, and recognized that the ewe, when due to lamb, starts expulsive efforts of variable strength, without result, rupturing the vagina or dying from shock or exhaustion from within a few hours to two or three days. Other ewes cease to strain and discharge parts of the fetus for a week and most die, presumably of toxemia. The authors also stated that in all ringwomb cases the os uteri would not relax, and in most cases discharge of the fetal fluid or approaching exhaustion of the ewe occurred before presentation for operation (6).

In most instances, if the animal is left more than 12 hours after rupture of the membranes, death of the lambs occur, and if left for two or more days, putrefaction occurs. Many cases diagnosed by the farmer as ringwomb are not so, but merely protracted cases of labor due to a variety of causes (uterine inertia, over-fat ewes, pregnancy toxemia, fetal oversize, fetal malpresentation, etc.).

Blackmore (32) observed two cases of incomplete cervical dilation in Suffolk ewes with abdominal distension. The ewes became recumbent, as a result of rupture of the prepubic tendon due to excessive abdominal pressure associated with the gravid uterus.

Ringwomb has not been successfully produced in a controlled experimental setting. However, Bengstsson and Schofield (35) produced a ringwomb like condition in ewes that had received daily doses of progesterone during the week before delivery. Hindson and Turner (44) also found that the total time for parturition to be completed was extended significantly and dilation of the cervix was slow, but all of the ewes delivered their lambs unassisted. Hindson and Turner (34) used a smaller daily dose of progesterone than Bengtsson and Schofield, but the dose was still larger than physiologically possible. Hindson and Turner (34) observed changes in 
the intrauterine pressure of normal and affected ewes using an endo-radio sonde transmitter. The amplitude of the pressure was diminished in spontaneous ringwomb cases.

O'Doherty and Crosby (113) showed that the rate of the preparturient decrease in progesterone is not a major determinant of the timing of birth, and this is consistent with the observation that exogenous progesterone given in physiological quantities is generally not effective in delaying spontaneous or induced parturition (54). Ewes which were underfed had higher progesterone concentrations at all times around lambing and there were negative linear relationships between colostrum yield and progesterone concentration both pre- and postlambing (113).

In an attempt to clarify the etiology of ringwomb, Hindson and Turner (34) performed an experiment with relaxin. The action of relaxin on connective tissue is mainly a dissolution and depolymerization of collagen fibers. Therefore, relaxin has the property of causing softening and dilation of the cervix, and a change in the appearance of the external genitalia in some animals. Because of this property, it has been used in humans and in animals, and under its influence the cervix has been found to soften and dilate. Hindson and Turner's (34) results using relaxin on ewes affected with ringwomb did not appear to be of practical value. In the female reproductive tract progesterone can stimulate the production of relaxin, which itself has little effect on tissue that is not estrogenically sensitized. Relaxin has been shown to be present in the ovaries of sheep and in very low concentrations in the blood.

Zhoa et al. (124) generated relaxin-deficient mice using gene targeting. The majority (15 of 17) of homozygous mice were fertile and produced normal litters. However, mammary development was deficient. The pups were unable to suckle and died within 24 hours of birth unless cross-fostered to a wild type foster mother. The nipples of relaxin-deficient mice did not 
enlarge significantly during pregnancy, and the histology retained the appearance of the virgin state. Breast parenchyma was underdeveloped at term even though milk was produced. Mammary ducts became grossly dilated in these animals. Heterozygous mice lactated normally. The interpubic ligament did not relax during pregnancy in relaxin-deficient mice (124). This may provide some explanation of the condition of Early Dilation Syndrome (EDS). Ewes affected with EDS have little or no udder development or a sudden overnight blooming of the udder. The cervix usually can be dilated by hand, but the lambs, although born alive, are weak and previable. There may be a strong possibility that ewes affected with EDS are genetically relaxin-deficient and heterozygous for ringwomb. Ewes with EDS can be affected for three consecutive years or more, where as ewes with ringwomb might be affected only once and experience normal parturition thereafter.

The use of $\mathrm{PGE}_{2}$, administered as an intracervical gel in the treatment of ringwomb in ewes, had no effect in causing softening of the cervix (79). This finding was disappointing because intracervically administered $\mathrm{PGE}_{2}$ induces an increase in cervical compliance identical to that seen during spontaneous parturition (77).

Hindson and Turner (34) performed cervical biopsies on ten ewes with ringwomb. Hemorrhage was only observed in one case. Inflammation of the stroma was a constant feature. This was assumed to be due to (a) the prolonged second stage labor, or (b) to manual interference. No firm conclusions could be drawn from the series of biopsies. It appeared that no fundamental abnormality would appear as it was accepted that a ewe might lamb normally both before and after an affected season. There is an indication that the collagen fibers in the cervix may not have fully undergone their normal changes. 
The effects of various factors pertaining to the reproductive performance of individual goats were studied during one season in pregnant dairy goats by Engeland et al. (115). The incidence of fetal loss was significantly higher in daughters of does that had suffered reproductive loss than in daughters of does without such a loss. Although pedigree analysis comprising the doe's sire, dam and dam's sire did not provide evidence of a genetic influence, there was a significant association between mother and daughter in the occurrence of reproductive inefficiency (115).

\section{$\underline{\text { Related Conditions }}$}

Early Dilation Syndrome (EDS) is similar to ringwomb but is considered to be separate from ringwomb. In early dilation syndrome, incomplete dilation of the cervix occurs approximately 7 to 14 days before term. Expulsion of the lamb(s) is not completed and assistance is required. If assistance is not rendered, there is lamb death with maceration leading to ewe septicemia, toxemia and death. Ewes delivering on their own have been found dead due to uterine prolapse or uterine tears with evisceration. The ewe has little or no udder development or a sudden overnight blooming of the udder and placental membranes protruding when presented. The cervix usually can be dilated by hand, but the lambs, although born alive, are previable. The syndrome occurs most frequently in ewe lambs and first-lambing 2-year-olds, but occasionally in

older ewes. Affected flocks can have over $30 \%$ morbidity. The syndrome occurs in all breeds and in all flock management situations. No common link has been found from nutritional, physiological, toxicological, or infectious disease investigations.

Ewes with diseases that cause abortion due to infectious agents may exhibit signs similar to ringwomb. Abortion with incomplete cervical dilation and abdominal straining may cause 
vaginal prolapse. Majeed (104) reported an association between ringwomb and vaginal prolapse in $18 \%(12 / 65)$ of the ewes that were observed. Pregnancy toxemia, consumption of poisonous plants, consumption of estrogenic plants, and lasalocid toxicity can cause ewes to display similar signs of ringwomb.

The cause of vaginal prolapse and the explanations for the development of the condition are still debatable. Edgar (7) was one of the first to suggest that sheep with vaginal prolapse could be suffering from hormonal imbalances. Since 1979, a hereditary disposition has been suspected (73). Stubbings (49) found lowered calcium concentrations in the plasma of animals with vaginal prolapse. A correlation also is known between elevated concentration of estrogen and lowered calcium concentrations. There are higher mean concentrations of plasma progesterone in the affected animals up to three days prior to parturition and a subsequent delayed fall until parturition (75). The causes of hormonal irregularities are found partly in the dam, but mainly in the fetus. The high progesterone in the animals with vaginal inversion and prolapse may be of placental origin and a manifestation of placental dysfunction (75). 


\section{CHAPTER 3}

\section{STATEMENT OF THE PROBLEM}

Parturition requires more than just contractions of the uterus. The increase in expulsive force must coincide with a decrease in resistance, as a result of softening of the collagen of the cervix, uterus, vagina and pelvic ligaments. Failure of these changes alone or in combination with fetal factors such as size, position, weight of fetal and placental tissues, and duration of second stage labor, might lead to difficult birth (dystocia). Dystocia results in hypoxic or traumatic injury to the fetus that is unfavorable to its survival or traumatic injury to the ewe and fetus. Dystocia is a major cause of perinatal mortality, because it leads to neonatal as well as parturient deaths both during and soon after parturition. Dystocia can be a major cause of lamb losses in the flock and might result in great economic hardship to the producer. Caesarean section is an effective method for treatment in most cases of dystocia and is safe for the dam as well as the fetus, especially when performed as early as possible after onset of labor. Dystocia is usually higher in meat breeds than in wool breeds. One reason for the increased susceptibility of meat breeds may be that there has been a reduction in natural selection against dystocia, resulting from intensive shepherding and creating a demand for continuation of that practice.

The most recognizable characteristic of ringwomb is the appearance of placental membranes protruding from the vulva with no sign of labor, but this is not without exception. Ewes with ringwomb do not show typical signs related to first-stage labor. Ewes do not seek isolation from the remainder of the flock, nor do they lack an appetite. There is no noticeable swelling of the vulva or relaxation of the pelvic ligaments. Udder development appears slow but normal. Milk 
letdown sometimes is impaired and teat canals may be very hard. When examining the ewe, the producer or veterinarian will find an undilated cervix allowing one or two fingers to be inserted through into the uterus. Uterine contractions are weak and uncoordinated. The continued ineffective uterine contractions may cause separation of the placenta from the cotyledons, which severs the blood supply from the dam to the fetal lamb. The condition may occur at the expected lambing date or be associated with a prolonged gestation up to 14 days. Affected flocks can have up to $35 \%$ lamb mortality and $20 \%$ ewe mortality. Various manual, medical, hormonal, and surgical treatments either alone or in combination have been used to treat such cases, with varying degrees of success.

If a ewe with ringwomb, suspected of being in the process of lambing, is left alone for several hours, no change in dilation will occur. In non-productive labor, the cervical ring starts to close two to three hours after partial opening (99). If the ewe is not provided assistance, spontaneous labor will occur after the fetus has died, usually 48 hours after initial onset of labor. Fetal autolysis can lead rapidly to septicemia and death of the ewe. In most cases, the ewe that survives will breed the following season. Ringwomb does not typically affect ewes in two consecutive seasons, but consecutive cases have occurred. The condition may have a genetic component, because it frequently occurs in some ewe families.

The condition of incomplete dilation of the cervix has been the subject of many reports over the years. There are numerous theories as to its etiology, incidence and treatment. The objective of this study was to determine the etiology of ringwomb in order to treat affected ewes and to prevent or eliminate the condition from occurring in a flock. 


\section{CHAPTER 4}

\section{MATERIALS AND METHODS}

Purebred Suffolk and crossbred Hampshire and Shropshire ewes were observed over five lambing seasons from 1993 to 1997 . The study was conducted on 24 clinical cases of ringwomb occurring in one flock on a Pennsylvania farm. The ages of the animals ranged from one to five years.

The animals suffering from ringwomb were subjected to the following treatments.

(1) Manual dilation of the cervix.

(2) In cases where manual dilation failed, the ewe was either euthanized (if straining) or left for observation for 12 to 48 hours.

(3) A caesarean section was performed on two animals suspected of being in labor, but not making any effort. 


\section{CHAPTER 5}

\section{RESULTS}

Ringwomb cases are listed and described below in five groups, classified according to common symptoms observed.

During the last one to three weeks before parturition, the ewes were kept in a large indoor group pen at night and observed at 11 PM and 2 AM. During nocturnal observations, characteristic labored breathing could be heard from ewes that were lying down. The ewes had a tendency to lie with their head and neck outstretched, appearing to have low abdominal pain. All ewes appeared to have normal behavior while grazing and exercising during the day. Discharge of abnormally large amounts of thick, clear mucus from the vagina occurred during this period in affected ewes.

Ewes that were suspected to be lambing, but were making no effort, had either rupture of the chorioallantois with a significant amount of allantoic fluid expelled from the vulva, or a distended amnionic sac containing red/purple fluid. In two cases, the placenta and three to five cotyledons were protruding. In all cases, the cervix did not dilate sufficiently to allow more than two fingers to be inserted into the uterus. Manual dilation of the cervix was possible in the five cases in Group 5. In the ten cases in Group 1, spontaneous dilation of the cervix occurred 48 hours after protruding membranes were first observed, yielding dead fetuses in the autolytic stage. 


\section{Group 1- Autolytic Twin or Triplet Fetuses}

$\underline{\text { Year }}$ Ewe Number

1993028,189

1994028,102

1995175,306

1996316,215

1997420,102

An abnormally large amount of clear mucus discharge was observed for as long as three weeks prior to lambing. Incomplete cervical dilation was detected between 7 and 15 days after the expected lambing dates. Udder development seemed slow but normal. Each ewe had placental membranes protruding from the vulva with no sign of labor. Between 24 and 48 hours later, the producer determined by vaginal examination, that the cervical dilation was at least three fingers. Forceful abdominal straining began, and putrefied, autolytic lambs were delivered from the uterus. After parturition, the ewes received $20 \mathrm{cc}$ of penicillin twice daily for three days. All ewes conceived the following season. In 1994, ewe 028 lost her wool three days after delivering putrefied lambs. The wool began growing approximately one month after parturition. Ewe 028 remained in the flock and was exposed in the fall of 1994 and 1995, but did not lamb in either season.

Group 2- Abdominal Straining Without Dilation

$\underline{\text { Year Ewe Number }}$

$1993169,178,180$

199504 
Incomplete dilation was detected up to 12 days after the expected lambing date. Placental membranes protruded from the vulva. Forceful abdominal straining and extensive bleeding from the vulva occurred after moving the ewe(s) to lambing pens. The cervix was found to be hard and unyielding at vaginal examination. The ewes died within two hours of initial observation due to trauma and laceration of the uterus and cervix. A veterinarian was not available at the time of the emergencies.

\section{Group 3-Recumbent with Signs of Septicemia and No Dilation}

Year Ewe Number

1993026

199405,024

Incomplete cervical dilation occurred with protrusion of placental membranes between four and seven days after the expected lambing date. There were no signs of first-stage labor, no decrease in appetite, and no isolation from the rest of the flock. The ewes were checked every two hours for a change in behavior or cervical dilation. Forty-eight hours after initial observation, the ewes were recumbent. The pulse rate was subnormal, and the body temperature was elevated to $103.5^{\circ} \mathrm{F}$. Severe abdominal straining occurred with no cervical dilation and no vaginal discharge. The ewes were euthanized, and autolytic lambs were observed at the post-mortem examination.

\section{Group 4 - Caesarean Section}

Year Ewe Number 
1993106

199404

Ewe number 106: The ewe was 14 days past the last possible lambing date. The ewe had full udder development. The ewe remained standing and shifted weight on all four legs for the remaining three days of gestation. The ewe was monitored for cervical dilation each of the last three days. Given the difficulty with the first two ewes of the season, the ewe was taken to the flock veterinarian for a caesarean section. The body temperature of the ewe was $104.5^{\circ} \mathrm{F}$. Large twin ram lambs were delivered alive. One lamb died 30 minutes after birth. The second lamb was artificially reared. The ewe was treated with $20 \mathrm{cc}$ of penicillin twice a day for three days. There was no evidence of a uterine or cervical torsion. The ewe was bred in the following season, but died three weeks before the subsequent expected lambing date.

Ewe number 04: A normal distended amnion was protruding from the vulva at the evening feeding. There was no sign of the fetal head or extremities. No other fluids were released to lubricate the vagina and vulva. The ewe showed no sign of labor, and continued to consume feed. The ewe was placed in a lambing pen and examined for cervical dilation. No dilation or relaxation of the vagina or cervix had occurred. The ewe was taken to the flock veterinarian for an emergency caesarean section one hour after initial observation. Large twin ram lambs were delivered. The first lamb died 10 minutes after birth. The second lamb died one hour after birth. The lambs were very weak and did not make any attempt to stand. The fetal lungs were pale in color and very firm. The umbilical cord was enlarged due to edema and was also pink in color in both lambs. The liver was also pale in color with slight necrosis in the center of the liver. Watery green fluid was present in the abomasum, small intestine, and large intestine. The 
kidneys were submitted for diagnosis, along with cotyledons and amniotic fluid from the ewe. No Campylobacter or Corynebacterium sp. were isolated. Bacterial and fungal cultures, viral FA, and microscopic examination of the fetal organs showed no evidence of infectious organisms. The necropsy report suggested ringwomb or early dilation syndrome as a possible diagnosis. The ewe was treated with penicillin for three days and had a full recovery from surgery. The ewe was bred in the following season and died in labor (see group 2). Both ewes had a body condition score of 3.25 (Scale: 1-thin: 5-fat).

\section{Group 5 - Early Dilation Syndrome}

Year Ewe Number

1993148,013

1994011

1995011

1996011

Ewe number 148: Incomplete dilation of the cervix occurred 13 days before the expected lambing date. Placental membranes protruded from the vulva with no sign of labor. Manual dilation was attempted for 30 minutes. Twin ewe lambs weighing four pounds each were delivered. The ewe had no udder development and no colostrum. The lambs were fed $3 \mathrm{oz}$. of goat colostrum. Both lambs were very weak and died $6-10$ hours after birth. The ewe died 12 hours after delivery due to uterine and rectal tears with extensive internal bleeding. Ewe number 011 (1994): Incomplete dilation occurred 16 days before the expected lambing date. The cervix was dilated manually, and assistance was required to deliver large twin ram lambs weighing 14 pounds and 12 pounds, respectively. The ewe had slight swelling of the vulva and 
vagina, but no abnormal bleeding was present. The ewe had little udder development and the colostrum was pale and water-like. The lambs were very weak and required assistance to stand and nurse. Colostrum supplement tablets were administered to both lambs, which remained with the ewe. Both lambs survived but were slow-starters. The ewe increased milk production in the third week of lactation.

Ewe number 011 (1995): Five days before the expected lambing date the ewe was suspected of lambing, but making no effort. A small, distended amnionic sac containing red/purple fluid was protruding from the vulva. Cervical dilation was slow, but progressed with manual dilation. Twin ram lambs were delivered alive but very weak and required assistance to stand and nurse. The ewe had little udder development and the colostrum was pale and water-like. Colostrum supplement tablets were administered to both lambs. Both lambs survived. The ewe was bred for the following season and repeated similar signs at lambing as in 1994 and 1995. The ewe developed mastitis and was culled from the flock after weaning. 


\section{CHAPTER 6}

\section{DISCUSSION}

Over $65 \%$ of the 24 cases of ringwomb were in 1993 and 1994. There are several reasons why this may have occurred. First, the same sire was used in 1993 and 1994 . Not all of the same ewes were affected both years, but all lambs tended to have a higher than average birth weight. Second, a 14\% protein ration with Bovatec (Hoffman-LaRoche, Basel, Switzerland) was fed during gestation and lactation in 1993. Bovatec (lasalocid) is used commonly as a feed additive at approximately $1 \mathrm{mg} / \mathrm{kg}$ of body weight for the prevention of coccidiosis and for improvement of feed efficiency. Studies in sheep and cattle have shown that lasalocid at increased levels can cause a toxic syndrome of congestive heart failure similar to that caused by the related drug monesin, but at a higher dose. Monensin has been reported to be toxic in sheep when fed at $8 \mathrm{mg} / \mathrm{kg}$ of body weight or at levels of $152-550$ parts per million in feed (94). A study on the effect of supplementation with concentrates and lasalocid during late pregnancy and lactation on productivity of Rambouillet ewes showed that ram lambs were significantly heavier than ewe lambs only at birth (88). Total weight gains between day 100 and day 146 of gestation were greatest in ewes supplemented with lasalocid (88). Monensin (not approved for sheep) and Bovatec have been fed to ewes in late gestation to control Toxoplasmosis (a protozoan parasite that causes abortion, encephalitis, and pneumonitis in sheep). Third, the ewes affected were all daughters or granddaughters of one particular ram used on the farm as a service sire in 1990 and 1991. Finally, in 1993 and 1994, inclement weather changes occurred frequently in January, 
February, and March. The ewes were housed for long periods with little exercise due to continuous snowfall, below freezing environmental temperatures, and blizzard-like conditions.

Evidence for Ringwomb as a hereditary condition that is sire related is presented in Appendix, Table 3. These data are from a closed ewe flock (1979-1998), where a new sire was purchased and introduced as the service sire every two years to prevent inbreeding. Sixty-eight percent (13/19) of the female offspring of sire $\underline{2}$ that were selected as replacements were affected with Ringwomb (ten) or Early Dilation Syndrome (three). Three of the six ewes not affected with ringwomb were only in the flock for one lambing season (one was hit by a car and killed, one was killed by dogs, and one was culled for a chronic foot abscess). The remaining three ewes not affected had single offspring and/or mostly male offspring. It is important to note that when sire 2 was the service sire to 46 ewes, no cases of ringwomb occurred, but $66 \%$ of the ewes serviced required assistance at lambing (N.J. Kerr, unpublished data). However, when sire $\underline{4}$ was the service sire, 12 of 43 ewes were affected with ringwomb and 3 of 43 ewes were affected with early dilation syndrome. It is interesting that $13 / 15$ were all daughters of sire 2 , and $2 / 15$ were granddaughters of sire $\underline{2}$ (Table 3 and Figure1). From these data, the author concludes that sire $\underline{2}$ introduced an autosomal recessive gene / gene mutation into the ewe flock and that the phenotype was not displayed until the carrier daughters were mated to another carrier. At least 13 of the 19 daughters kept as replacements were heterozygous for the recessive gene. Sire $\underline{3}$ was a non-carrier for this gene because $0 / 33$ ewes were affected when sire $\underline{3}$ was the service sire. However, sire $\underline{4}$ was a carrier of the recessive gene because 15 / 43 ewes were affected when sire $\underline{4}$ was the service sire. Sire $\underline{5}$ can also be classified as a carrier. All nine ewes affected when serviced by sire $\underline{5}$ were all daughters (four), granddaughters (five), or great-granddaughters (one) of sire $\underline{2}$ (Table 3 ). Only one daughter of sire $\underline{5}$ was affected, which was a great- 
granddaughter of sire $\underline{2}$, but was also serviced by sire $\underline{5}$ to produce the condition (inbred). This particular ewe had a strong maternal predisposition. Both the dam and granddam of this ewe had the condition at least once (Figure 1). When sire $\underline{5}$ was the service sire in a neighboring flock, lambs exhibiting hereditary chondrodysplasia (Spider Lamb Syndrome) were produced. Thus, sire $\underline{5}$ was also a carrier of Spider Lamb Syndrome. Sire $\underline{2}$ was gray pedigreed, meaning that both the sire and grandsire of sire $\underline{2}$ produced lambs with Spider Lamb Syndrome, but sire $\underline{2}$ did not produce Spider Lamb Syndrome in the closed ewe flock. Sire 1 was not a carrier because sire $\underline{1}$ was not in the pedigrees of 10 of the 19 affected ewes. It is concluded that sire $\underline{6}$ was not a carrier for Ringwomb or Early Dilation Syndrome.

In ewes aged one to three years old, the highest incidence of ringwomb occurred in ewes that were three years old at second parity (Table 2). Ewes four years old or older only represented $29 \%$ of the total number of ewes lambing in the flock. With the exception of one ewe affected at age four in third parity, the five ewes affected that were four years and older each repeated ringwomb, in which the first case for each ewe occurred between one and three years of age. Therefore, depending on whether or not a carrier sire is introduced, ewes appear most likely to be affected with ringwomb from one to three years of age (Table 2).

A number of ringwomb cases that occur during the second and third weeks of February (Table 1). This was first established in the 1950s, but was argued that mid-February was the peak time for lambing and therefore, the number of ewes affected for the number of ewes lambing during this period are not statistically significant. But, the author has noticed, when communicating with other producers that use multiple sires per breeding season, the condition occurs mainly in mid or late February independent of the peak of lambing season in both Fall and Spring lambing operations. One theory for this is that carrier rams may be more likely to 
breed around October 1, independent of ram introduction, but perhaps dependent on environmental conditions.

It was also observed that an increase in ringwomb and early dilation syndrome occurred in ewes that were either two years old at first parity (16.7\% of total ewes affected) or three years old at second parity (33.3\% of total ewes affected) (Table 2). Majeed and Taha (91) observed that ringwomb occurred more frequently in does two years old at first parity (24 / 32). This may further support the theory of a genetic component influencing the occurrence of ringwomb. One explanation for this similarity is that heterozygous ewe lambs may not mature at the expected time for the time of year that they are born, thus providing early indication of probable reproductive inefficiency. Thus, ewe lambs that do not breed in the first year may indicate a reproductive abnormality or inefficiency associated with Ringwomb.

Hindson and Turner (34) reported a correlation with multiple pregnancy and ringwomb. The total number of ewes lambing with either singles, twins, or triplets were not reported in comparison to the number of lambs born per affected ewe. It was stated that the large number of multiple pregnancies would seem to be significant (34). However, ewes two years old or older are more likely to have multiple births due to an increase in prolificy with increased age of the ewe. The number of ewes affected having one lamb could be significant if compared to the total number of ewes lambing that had only one lamb. The same could be true for the age of the ewe. If the total number of ewes lambing were grouped by age and parity in the study (34), then the majority of cases occurring could be contributed to a large number of ewes lambing that were over two years of age.

Engeland et al (115) may not have traced the pedigrees of animals with fetal loss back far enough to identify the problem sire responsible for the genetic introduction of the problematic 
cause. Engeland et al (115) analyzed pedigrees of the doe's sire, dam, and dam's sire, and did not find a significant association between mother and daughter in the occurrence of reproductive inefficiency.

Dystocia due to failure of the cervix to dilate is seen occasionally in the cow and the ewe and very rarely in the other domestic animals. Failure of the cervix to dilate properly at the time of parturition is associated with or observed in: uterine inertia, uterine torsion, metritis, placentitis, death of the fetus, diffuse peritonitis due to traumatic gastritis, hydrops of the fetal membranes, a terminal condition in severe septic or toxic diseases, mummified fetus, in certain abortions, preparturient paresis, and pregnancy toxemia in ewes.

Vaginal examination often permits identification of the cause of dystocia. It may be difficult to distinguish between the first stages of labor in a normal animal and failure of cervical dilation or uterine torsion in an animal with non-productive labor.

Ringwomb is not caused by malpresentation, mineral imbalance or deficiency, or premature lambing. Ringwomb does not result from consumption of red clover or feedstuffs containing estrogens. Unconjugated estrogens promote, whereas progesterone inhibits, the synthesis of $\mathrm{PGF}_{2 \alpha}$ in sheep.

Satisfactory results, either by surgical or medical treatment, depend on a correct early diagnosis and treatment of the condition. Ringwomb should be treated as early as detected. Treatment is important in reducing mortality rate of newborns and dams. Caesarean section is still the best treatment for ringwomb cases, although it is not an economical practice.

The cause of ringwomb is still not completely understood. Although, it is well established that the fetus influences its own birth. Fetuses that are homozygous recessive for the gene mutation responsible for ringwomb cause the condition in the heterozygous ewe. After careful 
review of lambing records from two flocks (one closed, one open) that spanned from 1986 to 1998, the author has found several factors that indicate that Ringwomb and Early Dilation Syndrome is genetically transmitted as an autosomal recessive gene.

1. Ringwomb has appeared in certain maternal bloodlines, and when those bloodlines have been inbred, the frequency of the condition has increased.

2. In sets of twin ewes, one ewe may exhibit Ringwomb and the other may never exhibit the condition at all. If the condition were due to an intrauterine effect, or an environmental factor such as nutrition, disease or weather conditions, both ewes should be affected.

Because ringwomb does not typically affect ewes in two consecutive seasons, it is proposed that the occurrence of ringwomb is dependent upon the genotype of the fetus. Fetuses that are homozygous recessive for the gene mutation responsible for ringwomb, appear to induce the condition in the heterozygous ewe. Although ringwomb occurs more often in ewes bearing multiple fetuses, ewes bearing singletons have been affected. Further research should investigate the possibility of an autosomal recessive gene in the fetus of ewes affected with ringwomb, perhaps located on the same chromosome as Spider Lamb Syndrome. 
Table 1. PARITY AND AGE OF EWES WITH RINGWOMB AND EARLY DILATION SYNDROME (EDS) IN A PENNSYLVANIA FLOCK

1993 Ewes with Ringwomb/EDS Date of Occurrence Parity Age Classification

178

148

189

106

169

028

180

026

013
02-16-93

02-17-93

02-19-93

02-22-93

02-27-93

02-28-93

03-03-93

03-27-93

04-19-93

2

3

3

23

$1 \quad 1$

23

12

$2 \quad 3$

$\begin{array}{ll}2 & 3 \\ 1 & 2\end{array}$

22

\section{2}

5

$4 \quad 5$

14

32

$2 \quad 1$

$3 \quad 2$

23

25

1994 Ewes with Ringwomb/EDS Date of Occurrence Parity Age Classification

028
102
05
024
04
011

01-24-94

02-06-94

$02-10-94$

$02-12-94$

$02-13-94$

02-13-94

$\begin{array}{lll}2 & 3 & 1 \\ 1 & 2 & 1 \\ 2 & 3 & 3 \\ 3 & 3 & 3 \\ 3 & 3 & 4 \\ 3 & 3 & 5\end{array}$

1995 Ewes with Ringwomb/EDS Date of Occurrence Parity Age Classification

04

175

011

306
02-20-95

02-25-95

03-08-95

03-17-95

44

45

44

$1 \quad 1$

1996 Ewes with Ringwomb/EDS Date of Occurrence Parity Age Classification

$\begin{array}{lllll}011 & 02-05-96 & 5 & 5 & 5 \\ 316 & 02-12-96 & 2 & 2 & 1 \\ 215 & 02-12-96 & 2 & 3 & 1\end{array}$

1997 Ewes with Ringwomb/EDS Date of Occurrence Parity Age Classification 420

102

02-23-97

03-12-97

$\begin{array}{lll}1 & 2 & 1 \\ 4 & 5 & 1\end{array}$


Table 2. INCIDENCE OF RINGWOMB AND EARLY DILATION SYNDROME GROUPED BY PARITY AND AGE IN A PENNSYLVANIA FLOCK DURING 1993-97

No. of $\%$ of No. of All \% Incidence of Age Parity Ewes Total Cases Ewes Lambing All Ewes Lambing

\begin{tabular}{|c|c|c|c|c|c|}
\hline 1 & 1 & 2 & 8.3 & 17 & 11.8 \\
\hline 2 & 1 & 4 & 16.7 & 26 & 15.4 \\
\hline 2 & 2 & 2 & 8.3 & 12 & 16.7 \\
\hline 3 & 2 & 8 & 33.3 & 19 & 42.7 \\
\hline 3 & 3 & 2 & 8.3 & 9 & 22.2 \\
\hline 4 & 3 & 1 & 4.2 & 13 & 7.7 \\
\hline 4 & 4 & 2 & 8.3 & 3 & 66.7 \\
\hline 5 & 4 & 2 & 8.3 & 8 & 25.0 \\
\hline 5 & 5 & 1 & 4.2 & 4 & 25.0 \\
\hline 6 & 5 & 0 & & 3 & 0 \\
\hline 6 & 6 & 0 & & 2 & 0 \\
\hline 7 & 6 & 0 & & 1 & 0 \\
\hline 7 & 7 & 0 & & 0 & 0 \\
\hline & & 24 & 99.9 & 117 & \\
\hline
\end{tabular}


Table 3. NUMBER OF EWES SERVICED AND NUMBER OF FEMALE OFFSPRING WITH RINGWOMB IN A PENNSYLVANIA FLOCK DURING 1993-97

\section{SERVICE SIRE:}

SIRE

$$
\underline{1} \quad \underline{2} \quad \underline{3} \quad \underline{4} \quad \underline{5} \quad \underline{6}
$$

Number of ewes:

\begin{tabular}{lllllll} 
with Ringwomb & 0 & 0 & 0 & 15 & 9 & 0 \\
without Ringwomb & 6 & 46 & 33 & 28 & 58 & 37 \\
\hline Total & 6 & 46 & 33 & 43 & 67 & 37
\end{tabular}

$\begin{array}{lll}\text { Percent Occurrence: } & 35 \% & 15 \%\end{array}$

FEMALE OFFSPRING:

\begin{tabular}{llllllll}
\hline $\mathrm{SIRE}$ & $\underline{1}$ & $\underline{2}$ & $\underline{3}$ & $\underline{4}$ & $\underline{5}$ & $\underline{6}$
\end{tabular}

Number of daughters

$\begin{array}{lllllll}\text { with Ringwomb } & 0 & 13 & 2 & 3 & 1 & 0\end{array}$

\begin{tabular}{lllllll} 
without Ringwomb & 12 & 6 & 17 & 14 & 32 & 11 \\
\hline Total & 12 & 19 & 19 & 17 & 33 & 11
\end{tabular}

$\begin{array}{lllll}\text { Percent Occurrence: } & 68 \% & 11 \% & 18 \% & 3 \%\end{array}$ 
Figure 1. Occurrence of Ringwomb in one selected ewe family showing the transmission of an autosomal recessive trait. Numbered males refer to sires and service sires in Table 3. Sire 2 introduced an autosomal recessive gene, which was not observed until the female offspring were serviced by sire 4 . Sires 4 and 5 were both carriers of the gene. Notice that the affected daughter of sire 5 was also serviced by sire 5 to produce the condition. Female offspring of sire 2 were unaffected when serviced by sire 3 . Ewes were affected in the season that dead twin or triplet fetuses were produced. Producers suspecting ringwomb in their flock should first trace the maternal pedigree, followed by sires and service sires.

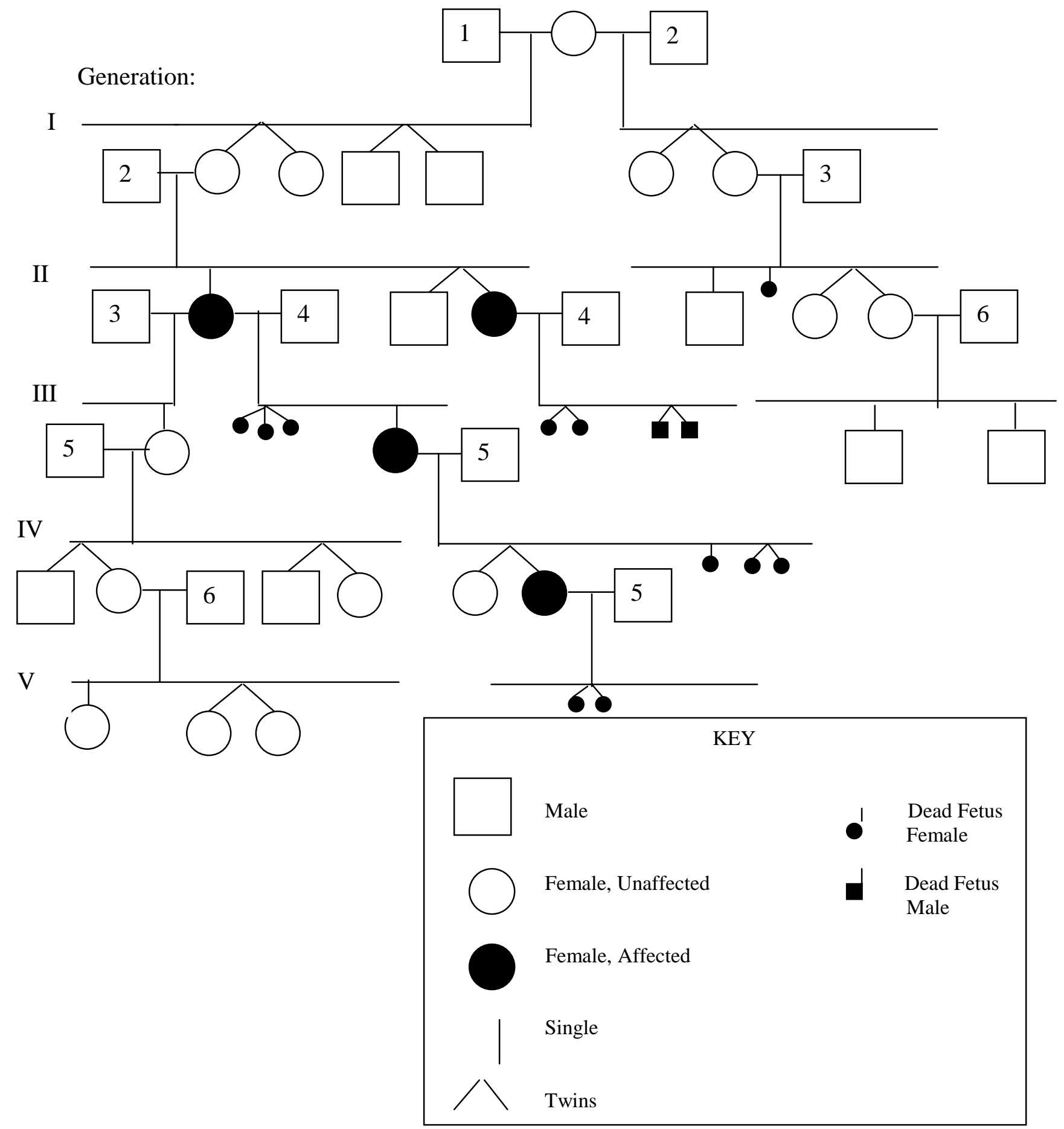


Figure 2. Occurrence of Early Dilation Syndrome in a selected maternal bloodline. Numbered males refer to sires in Table 3. Ringwomb did occur in this bloodline, but ewes with EDS did not exhibit characteristic Ringwomb. The dead lambs from ewes with EDS were born alive, but died within 48 hours after birth.

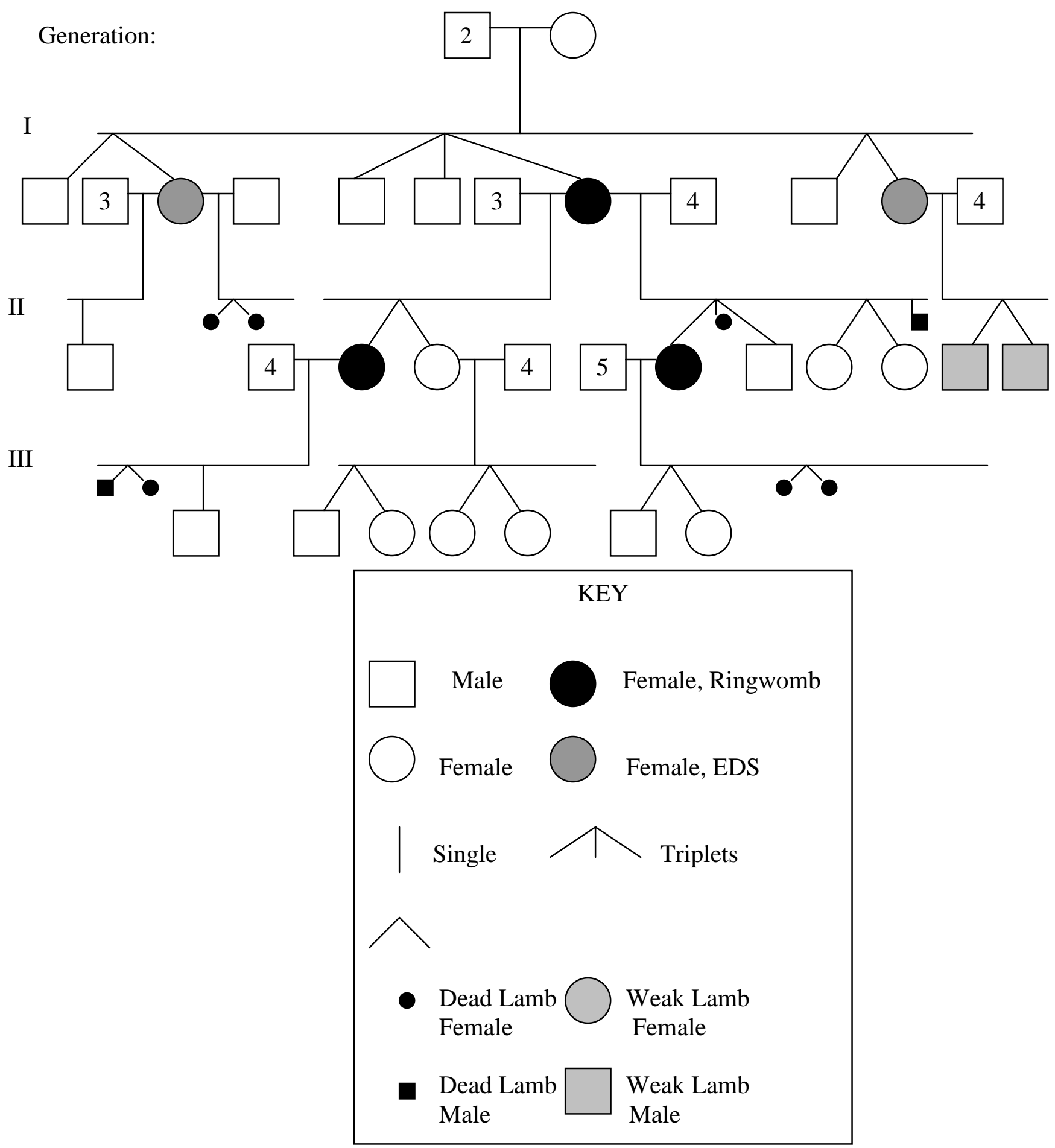




\section{REFERENCES}

1. Casida, L.E. and E.J. Warwick. 1945. The necessity of the corpus luteum for maintenance of pregnancy in the ewe. J. Anim. Sci. 4:34.

2. Harmar, J.B. and E.D. Mount. 1951. Caesarean section in the ewe in cases of so called "Ringwomb" or partial dilation of the os uteri. Vet. Rec. 63:457.

3. Yarrow, T.B. and G. Williams. 1952. Letter to the Editor. Vet. Rec. 64: 169.

4. Edwards, F.V. 1952. Letter to the Editor. Vet. Rec. 64:184.

5. Brownlie, W.M. 1952. Letter to the Editor. Vet. Rec. 64:215.

6. Mackinnon, M.M. and J. Bayliss. 1952. Caesarean section in the ewe. Vet. Rec. 64:512.

7. Edgar, D.G. 1952. Vaginal eversion in the pregnant ewe. Vet. Rec. 64:852.

8. Graham, E.F. and A.E. Dracy. 1953. The effect of relaxin and mechanical dilation on the bovine cervix. J. Dairy Sci. 36:772.

9. Csapo, A. 1956. Progesterone 'block’. Am. J. Anat. 98: 273.

10. Straiton, E.C. 1957. Bovine obstetrics with a note on so-called "Ring Womb" in Ewes. Vet. Rec. 69:395.

11. Pepper, R.T. 1957. Bovine Obstetrics. Vet. Rec. 69:442.

12. Walsby, J.B. and E.C. Straiton. 1957. Letter to the Editor. Vet. Rec. 69:443.

13. McIntee, D.P., A.L. McKerrell. and J. Sommerville. 1957. Bovine Obstetrics. Vet. Rec. 69:461.

14. Johnston, W.S. 1957. Letter to the Editor. Vet. Rec. 69:461.

15. Fraser, H. 1957. Letter to the Editor. Vet. Rec. 69:462.

16. Tutt, J.F.D. 1957. Letter to the Editor. Vet.Rec. 69:462.

17. Kenworth, R. 1957. Letter to the Editor. Vet. Rec. 69:462.

18. Walsby, J.B. 1957. Bovine Obstetrics. Vet. Rec. 69:478.

19. Edwards, F.B. and I.I. Jones. 1957. Letter to the Editor. Vet. Rec. 69:479-480. 
20. Barrett, E.P. 1957. Letter to the Editor. Vet. Rec. 69:480.

21. Gibson, A.C. 1957. Letter to the Editor. Vet. Rec. 69:480.

22. Fitzpatrick, R.J. 1957. The activity of the uterine cervix in ruminants. Vet. Rec. 69:713.

23. Schofield, B.M. 1957. The hormonal control of myometrial function during pregnancy. J.Physiol. Lond. 138:1.

24. Penny, R.H. 1958. Ring Womb in Sheep. Vet. Rec. 70:431.

25. Pickering, J.P. 1958. Ring Womb in two Ewes. Vet. Rec. 70:592.

26. Ellis, T.H. 1958. Observations on some aspects of obstetrics in the ewe. Vet. Rec. 70:952.

27. Hardy, F.B. 1958. Vaginal and uterine prolapse in the ewe. Vet. Rec. 71:41.

28. Blackmore, D.K. 1958. Letter to the Editor. Vet. Rec. 71:1002.

29. Coles, B.H. and B. Kirby. 1959. Hydramnios in the ewe. Vet. Rec. 71:787.

30. Rainey, J.W. 1959. Embrotomy in the ewe. Vet. Rec. 71:851.

31. Short, R.V. and N.W. Moore. 1959. Progesterone in blood: V. Progesterone and 20 $\alpha-$ hydroxy-pregn-4-en-3-one in the placenta and blood of ewes. J. Endocr. 19:288.

32. Blackmore, D.K. 1960. Some observations on dystokia in the ewe. Vet. Rec. 72:631.

33. Hindson, J.C. 1961. "Ring Womb" in the Ewe. Vet. Rec. 73:85.

34. Hindson, J.C. and Turner, C.B. 1962. Observations on incomplete dilation of the ovine cervix. Vet. Rec. 74:363.

35. Bengtsson, L. and B.M. Schofield. 1963. Progesterone and the accomplishment of parturition in the sheep. J. Reprod. Fertil. 5:423.

36. Jones, I.C., I.G. Jarrett, G.P. Vinson and K.J. Potter. 1964. Adrenocorticosteroid production of foetal sheep near term. J. Endocr. 20:211.

37. Silva, J.R. and D.E. Noakes. 1964. Pelvic dimensions, bodyweight and parturition in rare breeds of sheep. Vet. Rec. 76:242.

38. Csapo, A.I. and H. Takeda. 1965. Effect of progesterone on the electric activity and intrauterine pressure of pregnant and parturient rabbits. Am. J. Obstet. Gynec. 91:221. 
39. Alexander, G. and D. Williams. 1966. Progesterone and placental development in the sheep. J. Endocr. 34:241.

40. Liggins, G.C., L.W. Holm, and P.C. Kennedy. 1966. Prolonged pregnancy following surgical lesions of foetal lamb pituitary. J. Reprod. Fert. 12:419.

41. Hindson, J.C., M.E. Schofield, and Turner, C.B. 1967. The effect of a single dose of stilboestrol on cervical dilation in pregnant sheep. Br. Vet. Sci. 8:353.

42. Liggins, G.C. and P.C. Kennedy. 1968. Effects of electrocoagulation of the foetal lamb hypophysis on growth and development. J. Endocr. 40:371.

43. Liggins, G.C. 1968. Premature parturition after infusion of corticotropin or cortisol into foetal lambs. J. Endocr. 42:323.

44. Hindson, J.C. and C.B. Turner. 1969. Radio telemetric observation on uterine activity and ring womb in sheep. Vet. Rec. 81:190.

45. Bassett, J.M., T.T. Oxborrow, I.D. Smith and G.D. Thorburn. 1969. The concentration of progesterone in the peripheral plasma of the pregnant ewe. J. Endocr. 45:449.

46. Lyngset, O. 1970. Studies on reproduction in the goat. Gynecology and Obstetrics. Nor. Vet. Med. 22:414.

47. Liggins, G.G. and S. Grieves. 1971. Possible role for Prostaglandin F2a in parturition in sheep. Nature. 232:629.

48. Obst, J.M., R.F. Seamark and C.J. McGowam. 1971. Plasma progesterone concentrations during pregnancy and parturition of ewes grazing Yarloop Clover. J. Reprod. Fert. 26:259.

49. Stubbings, D.P. 1971. Observations on serum calcium levels in ewes in North Lincolnshire in relation to prolapse of the vagina and Incomplete Cervical Dilation. Vet. Rec. 81:296.

50. Ward, W.R. 1971. The etiology of ring womb or partial dilation of the cervix. Vet. Annual, $15^{\text {th }}$ issue, ed Grunseel and Hill, Bristol, pp 75-78.

51. Hindson, J.C. and C.B. Turner. 1972. The relationship of serum calcium to prolapsed vagina and ringwomb. Vet. Rec. 82:100.

52. Liggins, G.C., S.A. Grieves, J.Z. Kendall and B.S. Knox. 1972. Physiological roles of progesterone, oestradiol-17B and prostaglandin F2a in the control of ovine parturition. J. Reprod. Fert. (Suppl.) 16:85. 
53. Stabenfeldt, G.H., M. Drost, and C.E. Franti. 1972. Peripheral plasma progesterone levels in the ewe during pregnancy and parturition. Endocrinology. 90:(1)144.

54. Thorburn, G.D. and W. Schneider. 1972. The progesterone concentration in the plasma of the goat during the oestrus cycle and pregnancy. J. Endocr. 52:23.

55. Alexander, D.P., H.G. Britton, C.S. Corker, F. Naftolin and D.A. Nixon. 1973. Plasma luteinizing hormone and oestrogen in fetal and maternal sheep. J. Endocr. 56:333.

56. Challis, J.R.G. 1973. The binding of oestrogens to ovine serum albumin. J. Endocr. 56:319.

57. Liggins, G.C., R.J. Fairclough, S.A. Grieves, J.Z. Kendall and B.S. Knox. 1973. The mechanism of initiation of parturition in the ewe. Rec. Prog. Horm. Res. 29:111.

58. Rawlings, N.C. and W.R. Ward. 1973. Myometrial studies in the pregnant sheep. In: The Endrocrinology of Pregnancy and Parturition. Ed. C.G. Pierrepont. Alpha Omega Alpha Pub., Cardiff, Wales, Great Britain. P. 153.

59. Thorburn, G.D., R.I. Cox, B.J. Restall and W. Schneider. 1973. Prostaglandin F and progesterone concentrations in the utero-ovarian venous plasma of the ewe during the estrous cycle and early pregnancy. J. Reprod. Fert. (Suppl.) 18:151.

60. Currie, W.B. 1974. Regression of the corpus lutem of pregnancy and initiation of labour in goats. J. Reprod. Fert. 36:481.

61. Currie, W.B. and G.S. Thorburn.1974. Luteal function in hysterectomized goats. J. Reprod. Fert. 41: 501.

62. Emady, M., J.C. Hadley, D.E. Noakes, and G.H. Arthur. 1974. Progesterone in the perpherial blood of pregnant ewes. Vet. Rec. 92:168.

63. Flint, A.P.F., A. B.M. Anderson, P.T. Patten and A.C. Turnbull. 1974. Control of uteroovarian venous prostaglandin F during labour in the sheep: Acute effects of vaginal and cervical stimulation. J. Endocr. 63:67.

64. Flint, A.P.F., A.B.M. Anderson, P.A. Steele and A.C. Turnbull. 1975. The mechanism by which fetal cortisol controls the onset of parturition in the sheep. Biochem. Soc. Trans. 3:1189.

65. Anderson, A.B.M., A.P.F. Flint and A.C. Turnbull. 1975. Mechanism of action of glucocrticoids in induction of ovine parturition: Effect on placental steroid metabolism. J. Endocr. 66:61.

66. Arnold, G.W. and P.D. Morgan. 1975. Behavior of the ewe and lamb at lambing and its relationship to lamb mortality. Applied Animal Ethology. 2:25. 
67. Rawlings, N.C. and W.R. Ward. 1976. Changes in steroid hormones in plasma and myometrium and uterine activity in ewes during late pregnancy and parturition. J. Reprod. Fert. 48:355.

68. Currie, W.B. and G.D. Thorburn. 1977. Parturition in goats: Studies on the interactions between the foetus, placenta, prostaglandin $\mathrm{F}$ and progesterone before parturition, at term or at parturition induced prematurely by corticotrophin infusion of the foetus. J. Endocr. 73:263.

69. Korenman, S.G. and J.F. Hall. 1977. The role of cyclic AMP in the regulation of smooth muscle contraction in the uterus. Biol. Reprod. 16:1.

70. Thorburn, G.D., J.R.G. Challis, and W.B. Currie. 1977. Control of parturition in domestic animals. Biol. Reprod. 16:18.

71. Carnegie, J.A. and H.A. Robertson. 1978. Conjugated and unconjugated estrogens in fetal and maternal fluids of the pregnant ewe: A possible role for estrone sulfate during early pregnancy. Biol. Reprod. 19:202.

72. Lye, S.J. and S.G. Porter. 1978. Demonstration that progesterone 'blocks' uterine activity in the ewe in vivo by a direct action on the myometrium. J. Reprod. Fert. 52:87.

73. Behrens, H. 1979. Lehrbuch der Schafkrankheiten, p. 181. Berlin and Hamburg: Paul Parey.

74. Davey, D., J. Dommisse, M. MacNab and G. Allerton. 1980. Intravaginal Prostaglandin E2 for cervical ripening and induction of labour. S. Afr. Med. J. 58:516.

75. Smith, M.C. 1980. Caprine reproduction. In: Morrow, D.A. (ed), Current Therapy in Theriogenology. W.B. Saunders, Philadelphia, p. 971.

76. Butler, W.R., S.M. Fullenkamp, L.H. Cappiello and S. Handwerger. 1981. The relationship of placental lactogen, estradiol and progesterone. J. Anim. Sci. 53:1077.

77. Stys, S.J., B.L. Dresser, T.E. Otte and K.E. Clark. 1981. Effect of prostaglandin $\mathrm{E}_{2}$ on cervical compliance in pregnant ewes. Am. J. Obstet. Gynecol. 140:415.

78. Evans, C.A., T.G. Kennedy and J.R.G. Challis. 1982. Gestational changes in prostanoid concentrations in intrauterine tissues and fetal fluids from pregnant sheep, and the relation to prostanoid output in vitro. Biol. Reprod. 27:1.

79. Jones, G. W. 1982. The use of Prostaglandin $E_{2}$ in the treatment of ringwomb in sheep. Ph.D. Dissertation. University of Liverpool, England. 
80. Porter, D.C. 1983. The possible involvement of relaxin in the regulation of uterine contraction. In: Biology of Relaxin and its Role in the Human. Eds. M. Bigazzi, F.C. Greenwood and F. Gaspari. Exerpta Medica, Amsterdam. P.114.

81. Garcia-Villae, R., P.L. Toutain and Y. Ruckebusch. 1984. Pattern of electrical activity of the ovine uterus and cervix from mating to parturition. J. Reprod. Fert. $72: 143$.

82. Ledger, W.L., M.A. Webster, A.B. Anderson, A.C. Turnbull. 1985. Effect of inhibition of prostaglandin synthesis on cervical softening and uterine activity during ovine parturition resulting from progesterone withdrawal induced by epostane. J. Endocr. 105:227.

83. Grommers, F.J., L. Elving and P. Van Eldik. Parturition difficulties in sheep. 1985. Anim. Reprod. Sci. 9:365.

84. Sobiraj, A., G. Busse, H. Gips and H. Bostedt. 1986. Investigations into the blood plasma profiles of electrolytes, $17 \beta$-oestradiol and progesterone in sheep suffering from vaginal inversion and prolapse Ante Partum. Br. Vet. J. 142:218.

85. Wilsmore, A.J. 1986. Birth injury in a flock of Polled Dorset ewes. Br. Vet. J. 142:233.

86. Corah, L.R. 1987. Relationship of nutrition and dystocia. Agri-Practice. 8:26.

87. Parr, R.A., I.F. Davis, R.J. Fairclough and M.A. Miles. 1987. Overfeeding during early pregnancy reduces peripheral progesterone concentrations and pregnancy rate in sheep. J. Reprod. Fert. 80:317.

88. Shetaewi, M.M. and T.T. Rod. 1987. Effect of supplementation with concentrates and lasalocid during late pregnancy and lactation on productivity of Rambouillet ewes and development of wool follicles in their lambs. J. Anim. Sci. 65:351.

89. Nathanielsz, P.W. 1988. The regulation of the switch from myometrial contractures to contractions in late pregnancy: Studies in the sheep and monkey. In: Advances in Fetal Physiology. Eds. P.D. Gluckman, B.M. Johnson and P.W. Nathanielsz. Perinatology Press, Ithaca, N.Y. 8:409.

90. Thomas, V.M., M.J. McInerney and R.W. Knott. 1988. Influence of body condition and lasalocid during late gestation on blood metabolites, lamb birth weight and colostrum composition and production in Finn-Cross ewes. J. Anim.Sci. 66:783.

91. Majeed, A.F. and M.B. Taha. 1989. Preliminary study on treatment of ringwomb in Iraqi Goats. Anim. Reprod. Sci. 18:199.

92. Miller, S.M., R.E. Garfield and E.E. Daniel. 1989. Improved propagation in myometrium associated with gap junctions during parturition. Amer. J. Physiol. 256:130. 
93. Scott, P.R. 1989. Ovine Caesarian Operations: A study of 137 field cases. Br. Vet. J. 145:558.

94. Foreyt, W.J. 1990. Evaluation of toxicity of lasalocid in sheep. Sheep Research Journal. $6(3): 35$.

95. Thomas, J.O. 1990. Survey of the causes of dystocia in sheep. Vet. Rec. 127:575.

96. Boshier, D.P., R.A. Jacobs, V.K.M. Han, W. Smith, S.C.Riley, and J.R.G. Challis. 1991. Immunohistochemical Localization of Prostaglandin H Synthase in the sheep placenta from early pregnancy to term. Biol. Reprod. 45:322.

97. Thorburn, G.D. 1991. The placenta, prostaglandins and parturition: A review. Reprod. Fert. Dev. 3:227.

98. Scott, P.R., L.D. Murray and C.D. Penny. 1992. A preliminary study of serum haptoglobin concentration as a prognostic indicator of ovine dystocia cases. Br. Vet. J. 148:351.

99. Ghosh, A., F. Yeasmin and M.G.S. Alam. 1992. Studies of ringwomb in Black Bengal Goats (Capra hircus). Theriogenology. 37:527.

100. Peters, A.R. and C.N. Dent. 1992. Induction of parturition in sheep using dexamethasone. Vet. Rec. 131:128.

101. Conley, A.J. and J.I. Mason. 1993. Steroidogenic enzymes. In: Molecular Membrane Acetocoids. Eds. G.E. Rice and S.P. Brennecke. CRC Press, Boca Raton, FL p.1.

102. Nathanielsz, P.W. 1993. A time to be born: How the fetus signals to the mother that it is time to leave the uterus. Cornell Vet. 83:181.

103. Wimsatt, J., P.W. Nathanielsz, and J. Sirois. 1993. Induction of prostaglandin endoperoxide synthase Isoform-2 in ovine cotyledonary tissues during late gestation. Endocrinology. 133:1068.

104. Majeed, A.F., M.B. Taha and O.I. Azawi. 1993. Cesarean Section in Iraqi Awassi ewes: A case Study. Theriogenology. 40:435.

105. Berdusco, E.T.M., K. Yang, J.R.G. Challis and G.L. Hammond. 1993. Tissue distribution of alpha1-Proteinase inhibitor messenger ribonucleic acid and its regulation by glucocrticoids in fetal and neonatal sheep. Biol. Reprod. 49:816.

106. Wray, S. 1993. Uterine contraction and physiological mechanisma of modulation. Amer. J. Physiol. 261:C1. 
107. Bryant-Greenwood, G.D. and S.Y. Yamamoto. 1995. Control of peripartal collagenolysis in the human chorion-decidua. Am. J. Obstet. Gynecol. 172:63.

108. Majeed, A.F. and M.B. Taha. 1995. Obstetrical disorders and their treatment in Iraqi Awassi ewes. Small Ruminant Research. 17:65.

109. Majeed, A.F., H.I. Al-Sadi and A.M. Ridha. 1995. Ovine placenta related to binucleated cells in fetal membrane retention. Small Ruminant Research. 17:97.

110. Owiny, J.R. R.O. Gilbert, C.H. Wahl, P.W. Nathanielsz. 1995. Leukocytic invasion of the ovine cervix at parturition. J. Soc. Gynecol. Investig. 2:593.

111. Gill, J.W. and B.J. Hosking. 1996. Effects of prenatal steroid environment on fetal size and morphology in twin sheep. Aust. J. Agri. Res. 47:1315.

112. Wu, W.X., J.B. Derks and P.W. Nathanielsz. 1996. Effects of glucocorticoids on estrogen receptor messenger ribonucleic acid in the pregnant ovine myometrium in vivo and in vitro. Biol. Reprod. 54:230.

113. O'Doherty, J.V. and T.F. Crosby. 1996. The effect of diet in late pregnancy on progesterone concentration and colostrum yield in ewes. Theriogenology. 46:233.

114. Bogic, L.V., S.Y. Yamamoto, L.K. Millar, and G.D. Bryant-Greenwood. 1997. Developmental regulation of the human relaxin genes in the decidua and placenta: overexpression in the preterm premature rupture of the fetal membranes. Biol. Reprod. 57:908.

115. Engeland, I.V., H. Waldeland, O. Andresen, and A. Tverdal. 1997. Foetal loss in dairy goats: an epidemiological study in 515 individual goats. Anim. Reprod Sci. 40:45.

116. Smith, K.H., A.I. Musah, S.J. Cho, C. Schwake and L.L. Anderson. 1997. Continuous infusion of relaxin on periparturient progesterone oxytocin and relaxin plasma concentrations and time of parturition in beef heifers. Anim. Reprod. Sci. 46:15.

117. Wu, W.X.,X.H. Ma, Q.Zhang, L. Buchwalder and P.W. Nathanielsz. 1997. Regulation of Prostaglandin Endoperoxide H Synthase 1 and 2 by estradiol and progesterone in nonpregnant ovine myometrium and endometrium in vivo. Endocrinology. 138:4005.

118. Andrews, A.H. 1998. Editorial: The treatment of inherited conditions in animals. Vet Rec. 156:3. 
119. Burger, L.L. and O.D. Sherwood. 1998. Relaxin increases the accumulation of new epithelial and stromal cells in the rat cervix during the second half of pregnancy. Endocrinology. 139:3984.

120. Scott, P.R. and M.E. Gessert. 1998. Management of ovine vaginal prolapse. In Practice. 20:28. 1998.

121. Summerlee, A.J., D.G. Ramsey and R.S. Poterski. 1998. Neutralization of relaxin within the brain affects the timing of birth in rats. Endocrinology. 139:479.

122. DeJonghe, S., B. Ramakers, P. Simoens, and R. Ducatelle. 1999. High incidence of otognathia in a sheep population. Vet. Rec. 144:96.

123. Tsatas, D., M.S. Baker and G.E. Rice. 1999. Differential expression of proteases in human gestational tissues before, during and after spontaneous-onset labour at term. J. Reprod. Fert. 116:43.

124. Zhoa, L., P.J. Roche, J.M. Gunnersen, V.E. Hammond, G.W. Tregear, E.M. Wintour and F. Beck. 1999. Mice without a functional relaxin gene are unable to deliver milk to their pups. Endocrinology. 140: 


\section{VITA}

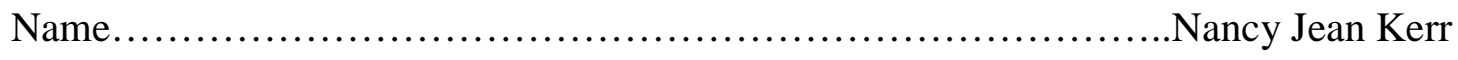

Parents...................................................James R. Kerr Sue Ann Kerr

Birthplace.......................................Uniontown, Pennsylvania

Date of Birth.............................................une 29, 1975

Schools Attended:

Nemacolin Elementary School..................................1980-1984

Nemacolin, Pennsylvania

Central Elementary School.....................................1984-1987

Carmichaels, Pennsylvania

Carmichaels Area Jr./Sr. High School...............................1987-1993

Carmichaels, Pennsylvania

Pennsylvania State University.................................1993-1997

University Park, Pennsylvania

Degrees Received:

Bachelor of Science in Animal and Biological Sciences..................1997

Pennsylvania State University

University Park, Pennsylvania 